\title{
Canadian Cinema
}

\author{
By Gerald Pratley
}

Spring 1997 Issue of KINEMA

\section{CANADIAN CINEMA: A SUMMING UP OF THE YEAR IN REVIEW}

SEPTEMBER is the month when new Canadian films appear and we discover what's been going on in the underworld of feature film production. They arrive at the Montréal, Halifax, Toronto and Vancouver festivals and the nomination screenings for the Genie Awards. Except for the Montréal festival's catalogue, which is content to simply summarise the stories of the films being shown, the rest would have us believe that all their entries, Canadian, in particular, are of the most profound importance, skilful, aware and socially, politically and sexually significant!

Expectations aroused by these endorsements are seldom fulfilled, and where our films are concerned much is made of "first features" with one overly-excited programmer telling us "that there are more first-time directors than ever before" forgetting that every year we have first directors by the score who, fortunately in most cases, are never heard from again.

There is little need going to great lengths here analyzing what goes wrong with the majority of our films: their shortcomings are almost entirely due to the one-dimensional single-plot nature of their stories and screenplays. This is not to speak unkindly of our writers. Most never get the opportunity to either write or sell screenplays because we have too many auteurs writing their own scripts. Few are capable of doing them well. The many experienced writers who have sold screenplays made into successful films and tv movies are now put aside in favour of writer-directors making their own personal pictures. The result is far from being encouraging -- but one would never think so from the praise heaped by certain critics on our films of little merit. As in previous years a large body of the new work is that of the auteurs.

Between them the four festivals and the Genies came up with 50-odd feature films; several of them, Long Day's Journey into Night, Lilies, Lulu, Swann, Fish Tale Soup, Shoe Maker, Kissed, Crash, Hard Core Logo, Never Too Late, Le Polygraphe, have opened in specialised cinemas.

In considering them we may as well get the biggest wreck out of the roadway, this being Cronenberg's Crash (the first letter should be T). It is not that this latest drive into depravity is offensive, ugly and morally empty, it is that from beginning to end this loathsome piece is unbelievable, clumsily constructed and unconvincing. His leading American actors play poorly as they climb from their ruined cars and become engaged in aggressive sexual encounters in every impossible place and position. One of my Ryerson University students summed it up rather well, I thought: "crash-sex, crash-sex, crash-sex, dead and boring". Cronenberg's screenplay is based on J.G. Ballad's far from being boring novel.

Dead and boring too is Kissed by Lynne Stopkewich (script by Angus Fraser and Stopkewich from a story by Barbara Gowdy) concerning a young woman obsessed with having sex with dead and embalmed men in a funeral home where she works. There is no clear understanding of her abnormal behaviour; it is not enough to say that she wants to "go to the other" whatever that is and establish this with a high-tech white-out on screen when she achieves orgasm with her dead bodies -- surely a physical impossibility? This film however might persuade more men to consider cremation.

With the exception of last year's The Confession by Lepage we seem to be out of luck with our AngloCanadian co-productions. There are three this year: Swann (script by David Young from the novel by Carol Shields directed by Anna Benson Gyles); Sweet Angel Mine (scripted by Sue Maheu, Tim Willocks, directed by Curtis Radclyffe); and Intimate Relations (script and direction by Philip Goodhew). Like Camilla of two years ago, Swann, about a New York writer who comes to a small Ontario town in search of a poet, is lost in confusion and uncertainty, it comes from nowhere and goes nowhere being almost untranslatable from book to film; Sweet Angel Mine is a horror tale set in Nova Scotia of the old dark house kind made watchable by the wickedly erotic performance of Alberta Watson -- surely one of our least appreciated actresses. Intimate Relations is by far the best, but it was made in the UK with little if any of its creativity being Canadian. Neither is there much that is Canadian -- other than ubiquitous and reliable Kenny Welsh -- in Turning 
April, an Australian co-production, (script and direction by James Nichol) about a wealthy young woman taken hostage in an odd yet likeable mixture of comedy-drama.

\section{Québec}

Québec's contribution this year is disappointing: Pudding Chomeur (Bread Pudding, written and directed by Gilles Carle) is a controversial social mish-mash both cynical and satirical about faith, happiness, love and anything else Carle feels like throwing into the pudding; J'aime, J'aime Pas (written and directed by Sylvie Groulx) is a truly affecting little low-budget film about a 17-year-old raising her son alone in life; $L e$ Cri de la Nuit (written and directed by Jean Beaudry) is not up to his high standard this being a slight mixture of fanciful romance and sentimentality; in Erreur Sur la Personne (written and directed by Gilles Noel) a police officer becomes involved with a beautiful woman in search of her own self; Caboose (written and directed by Richard Roy with writers Michel Michard and Odile Poliquin) is another police story, this one rough and violent as a woman constable saves the life of an ex-policeman; Le Polygraphe (written and directed by Robert Lepage) concerns a woman who decides to make a film about the unsolved murder of her friend. Compelling, but somewhat confusing, even Lepage admits the narrative lost its way; Le Silence des Fusils (Silencing the Guns) (written and directed by Arthur Lamothe) from a gentle opening becomes a gripping account of murder on an Indian Reserve and of racism and bigotry on the part of the police and the local fishing families; Le plante humaine (written and directed by Pierre Hébert) takes a meditative semidocumentary and partly animated approach in revealing the thoughts of a retired librarian going about his ordinary daily tasks; Le Nuit du Deluge (The Night of the Flood) (written and directed by Bernard Hebert) is a dance film in experimental terms drawing on the myths and legends of Brittany to portray life and death in a world of dreams -- very abstract and somewhat strained; L'escorte (The Escort) (directed by Denis Langlois and written by Langlois and Bernard Lachance) is a genuinely affecting and intimate study of two young gay men seeking and being afraid of love and companionship; and possibly the best of the bigger pictures from Québec is Sous-sol! (Not Me) (written and directed by Pierre Gang) about an 11-year old boy coming to terms with his disturbed family life -- not always convincing but concerned, honest and revealing.

\section{Among the others}

Lilies (Les Feluettes, directed by John Greyson and adapted from Nichel-Marc Bouchard's play by the author, Greyson and Linda Gaboriau). This is a very gay piece about a gloomy subject involving a bishop visiting a prison and forced to watch a gang of inmates stage a re-enactment of his youthful days as part of a homosexual group. Part of the action, as though in memory, takes place in the countryside. It is coy, confused and tedious. The Cockroach that Ate Cincinnati (directed by Michael McNamara, screenplay by Alan Williams based on his plays The Cockroach Trilogy) takes the form of a film showing a tv crew filming the talkative humorist, Alan Williams, who delivers a non-stop rant about the disillusionments of today's society. At times one cannot help but feel that enough is enough.

Live Bait (written and directed by Bruce Sweeney) and inappropriately titled, is easily the best of the Genie-nominated entries telling with sensitivity and understanding of the coming-of-age disappointments of a young university student who has no luck with the ladies until he meets a lively older woman; Shoemaker (directed by Colleen Murphy and written by Jaan Kolk) tells a likeable if unbelievable and slight story of a simple man who falls in love with a knowing travel agent, beautifully played by Alberta Watson, who saves a faltering script; with Hard Core Logo (directed by Bruce McDonald and written by Noel S. Baker based on the novel by Michael Turner), the best that can be said of this mock-documentary about a group of punk musicians is that moviegoers wanting to spend time with spitting, swearing, kissing, scruffy obnoxious, illiterate characters will be greatly rewarded. McDonald has put it together with an unflagging energy wasted on worthless material. And the completion of a trilogy? What trilogy? Does a road running through three of his films make a trilogy? Of course not. It is however one of the few films in this year's collection boldly identifying its Canadian places; a pity McDonald could not have taken a different road.

Lulu (directed by Scrinivas Krishna and written by Robert Armstrong and Krishna) is frankly a mess and defiles the work and memories of Wedekind and Louise Brooks. No wonder Lulu is frustrated by "a terrible past and a troubled present". She doesn't know what's going on and neither will the audience. The immensely enjoyable Indian actor, Saeed Jaffrey, is wasted in a brief appearance; Jo's So Mean to Josephine (written and directed by Peter Wellington) holds the promise of a light comedy but this was not to be. An uneven story about a surly and barely educated young man who becomes jealous of his girl friend's more promising 
way of life it bumps along with an exasperating failure to come to grips with an interesting premise; Never Too Late (directed by Giles Walker and written by Donald Martin) comes from the Tom Berry firm of pseudoAmerican Canadian cinema and attempts to be a comedy-thriller- romance concerning four old friends in a retirement home who discover the owner is diddling them of their savings; it's long on the tooth, slow in development and superficially senile.

\section{Lower on the List}

The Boys' Club (directed by John Fawcett and written by Peter Wellington) -- a nasty and irresponsible melodrama about three young boys trapped by a murderer. Is it not morally wrong to expose juvenile players to exploitive material such as this? What were their parents' thinking of? The Drive (directed by Romy Goulem and written by Goulem and Adam Barken from Barken's play) is another questionable melodrama about three aimless Saturday-nighters abducted by an ex-convict; Honeymoon written and directed by Joan Carr-Wiggin) is an instantly forgettable romantic comedy about the misadventures of a honeymoon couple complicated by well-intended friends and a stranger who works miracles; Trouble (written and directed by Paul Di Stefano) -- two not very bright losers, our favourite stereotypes, plan a robbery and become mixed up with other minor crooks playing the same game. Its amusing intent is blunted by unnecessary violence; Cat Swallows Parakeet and Speaks! (written and directed by Ileana Pietrobruno), is a failed attempt at satirical comedy drawn from the lurid headlines in the tabloid press: It takes on its own weird sense of humour and surreal dream-like settings but amounts to little that is satisfying either as social commentary or clever entertainment; Fish Tale Soup (written and directed by Annette Mangaard) is a bad-taste soup embarrassingly awful and inept about a young wife who wants a baby. Remy Girard is wasted playing his version of Depardieu's Bogus character.

\section{Are these films really Canadian?}

In 1964 Sidney Furie, frustrated by the lack of opportunities to make films in Toronto, went to London where he directed The Ipcress File with Michael Caine playing secret-agent Harry Palmer. It was highly successful and never described as being Canadian. Thirty years later the Montréal director, George Mihalka, goes to London to direct Bullet to Beijing (written by Peter Welbeck) with Michael Caine playing the now much older and out-of-work and not-so-secret agent, Harry Palmer. Why is this considered a Canadian film? Rowing Through (directed by Masato Harada and written by Harada and Will Aitken) although filmed in Montréal follows a story set in the United States concerning the trials and tribulations of American rowers training for the Olympics. Kenny Welsh pops up here too!; Screamers (directed by Christian Duguay and written by Dan O'Bannon and Miguel Tejada-Flores) takes the form of a futuristic horror gloomily predicting the end of the human race through screaming devices; Profile for Murder (directed by David Winning and written by Steve Fisher) is a violent sex-crime tired-tale set in Seattle among the usual legal types; The Size of Watermelons (directed by Kari Skoland and written by Rob Stefaniuk) goes to Venice Beach, California, where three losers try to make a documentary film; Hustler White (written and directed by Bruce LaBruce and Rick Castro) follows a silly and shocking comic porno-tour of LA's gay sex trade; Kids in the Hall Brain Candy (directed by Kelly Makin and written by Bruce McCulloch, Kevin McDonald, Mark McKinney, Norm Hiscock, Scott Thompson) is their first feature film, supposedly a comedy about depression which turns out to be a somewhat depressing non-comedy. Fire (written and directed by Deepa Mehta) is a shallow drama, pitting desire against repression, saved only by the sympathetic performances of its Indian cast playing out a weakly told story of two neglected wives who become lovers. This picture, made entirely in India, was accepted as Canadian by the Toronto Festival's "Perspective Canada" programme because the director is a Canadian citizen. Well, so are Norman Jewison, Arthur Hiller and Dan Patrie and several other Canadians working out of the country. Will their films be considered Canadian at next year's festival?

\section{The Enemy Wins Again}

In 1956 Tyrone Guthrie filmed the stage production of Oedipus Rex which he directed at the Stratford Festival. The main actors were Douglas Campbell, Tony van Bridge, Robert Goodier, Eleanor Stuart and William Hutt. In the years between, Norman Campbell filmed Stratford's stage productions of operettas by Gilbert and Sullivan. As film and tv records they were effective and inexpensive and played well on television. This year, David Wellington became so enraptured with Stratford's staging of Eugene O'Neill's Long Day's Journey into Night that he spent over two million dollars building a set and filming the stage production with William Hutt, Martha Henry, Tom McCamus, Peter Donaldson and Martha Burns. As a filmed play it 
remains a play valuable to those who could not travel to Stratford.

However, is one permitted to ask why do we spend this amount of money filming an American play which, we hear, may not even be shown in cinemas in the US? It is laudable to have a record of our actors' performances, but this could have been achieved just as well by filming the stage production (and not in widescreen), and showing it on television. The audience would certainly be much larger than those who went to the cinema to see Wellington's transfer from stage to screen. Later, on television, it was shown "flat".

\section{Summing Up}

The actors are fine, the production values are good, the cinematography is always commendable, the sound is clear; but inexperienced first-time directors should not be expected to make masterpieces the first time round and too many of the films being made should never have been attempted in the first place. The result: millions of public money has been spent by funding agencies on films the public has little interest in seeing.

\section{Out in Space yet Unseen}

Suburban Legend (written and directed by Jay Ferguson) "Jason has to resort to television and pornography for his information about women"; Boozecan (directed by Nicholas Campbell and written by Luciano Diana) "Life in a boozecan, an illegal after-hours drinking club"; Bubbles Galore (directed by Cynthia Roberts and written by Roberts with Georgina Knight) "Bubbles is a porn super-star who produces her own brand of adult entertainment"; For those Who Hunt the Wounded Down (directed by Norma Bailey and written by David Adams Richards) "Jerry Bines, a charismatic ex-con tries to rebuild his broken family"; Lexx: The Dark Zone Stories (written and directed by Paul Donovan and others in a co-production with Germany) "two unlikely humanoids steal a giant plant destroying spaceship"; Carver's Gate (directed by Sheldon Inkol and written by Doug Bagot, Timothy Lee, Inkol) "Almost one hundred years into the future, humanity nears extinction"; Frankenstein and Me (directed by Robert Tinnell and written by David Sherman and Richard Goudrau) "A twelve-year old boy loves monsters and one day finds the real Frankenstein"; Captains Courageous (directed by Michael Anderson and written by John McGreevy) a new version of Kipling's famous novel; Joe's Wedding (Venice by Moonlight) (written and directed by Michael Kennedy) "in three days Joe is to marry the boss's daughter but today he is staring at a gun held in his lover's shaking hands"; Airport In (directed by Erik Whittaker and written by Scott Tate, Jonathan Williams, Whittaker) "An RCMP officer is forced to confront his old ghosts"; American Beer (directed by Grant Harvey and written by Brent Kawchuk, Jordan Kawchuk, Harvey) "Four young Canucks explore American pop-culture reference points"; Drawing Flies (written and directed by Matt Gissing and Malcolm Ingram) "Five smart Ontarians come west to the promised land of BC"; The Willing Voyeur (written and directed by Richard Kerr) "A murder mystery set in Regina in the future".

\section{Author Information}

Gerald PRATLEY, OC, LLD, started his career as film critic with the CBC. In 1969, he founded the Ontario Film Institute which he directed until 1990. He has written several books and numerous articles on film, including Torn Sprockets, a history of Canadian cinema. He taught Film History in universities in Toronto and Waterloo, Canada and holds three honorary degrees from Canadian and US universities.

Gerald A. Pratley (1923-2011) was born and educated in London, England, and came to Canada in 1946. He started working in Toronto for the $\mathrm{CBC}$ as a scriptwriter. He was drawn toward working in motion pictures, and became, in 1948, the CBC's first film critic and commentator.

Gerald Pratley broadcast three programmes a week, Pratley at the Movies, The Movie Scene, Music From the Films, and others, until 1975. During this time he also became the first post-war chairman of the Toronto Film Society, chairman of the Toronto and District Film Council and co-founder of the A-G-E Film Society and correspondent for international magazines such as Films and Filming, Film In Review, Variety, Hollywood Quarterly and International Film Guide. During the 1950s he wrote for Canadian Film Weekly and Canadian Film Digest.

He became known as a speaker on all aspects of motion picture art and industry, and was invited to teach film history at the University of Toronto, York University, University of Waterloo, Seneca College and Ryerson 


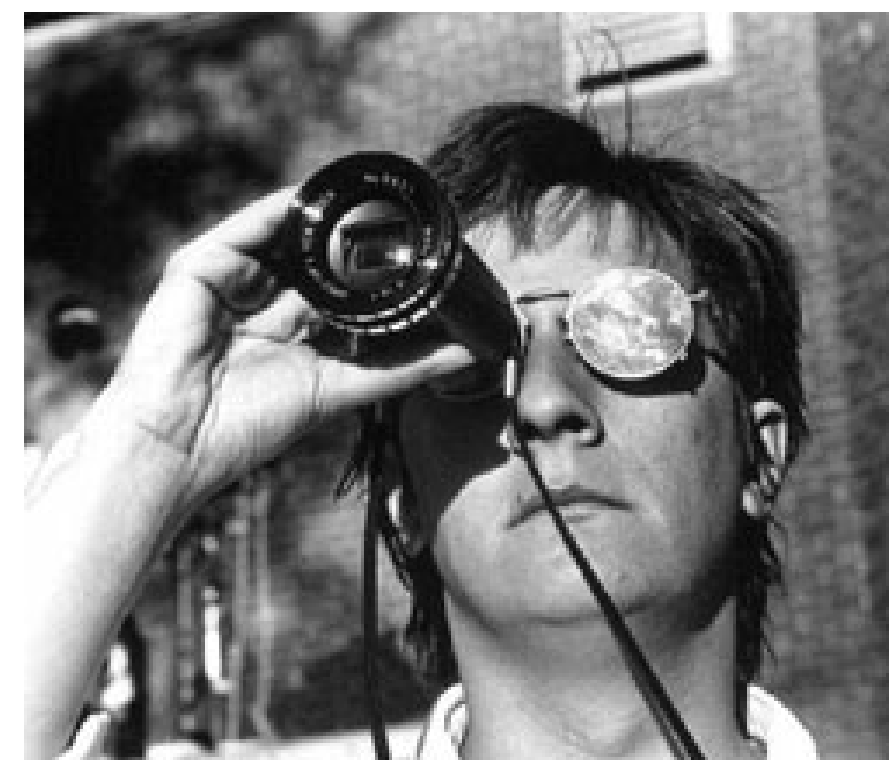

Figure 1: Director Robert Lepage

Polytechnical University, with individual lectures being given at many other Canadian and US universities and colleges. He has served as a member of various judging panels of competitions and festivals, being one of the members of the first Canadian Film Awards in 1949.

From 1970 to 1975 he was the director of the Stratford (Ontario) International Film Festival, and from 1969 to 1976 he was Chairman of the International Jury of the Canadian Film Awards. He has attended all the world's leading festivals of film, and in particular, for 30 years, the Cannes Festival as CBC correspondent. He has written six books, The Films of Frankenheimer: Forty Years in Film; The Cinema of John Frankenheimer; The Cinema of Otto Preminger; The Cinema of David Lean; The Cinema of John Huston, and Torn Sprockets, a history of the Canadian cinema.

Gerald Pratley has served on the Advisory Boards of the film departments of Ryerson Polytechnical University and Humber College, and as a member of the programme committee of TV Ontario. In 1968 he became the founder-director of the Ontario Film Institute of the Province of Ontario, an organization which has distinguished itself in archival holdings and public service and is known since 1990 as the Cinematheque of Ontario. He taught Film History courses at the Department of Film and Photography, Ryerson Polytechnic University, Toronto and the University of Waterloo.

In 1984, Gerald Pratley was made a Member of the Order of Canada and in 2003 Officer of the Order of Canada for his service to Canada through film appreciation. He holds Honorary Degrees in Letters and Fine Arts from York and Waterloo Universities (Ont., Canada) and Bowling Green State University (Ohio, USA).

In 2002, Gerald Pratley received a Special Genie Award from the Academy of Canadian Cinema \& Television in recognition of his lifelong dedication to the promotion and his exceptional support of Canadian cinema.

He died on 14 March 2011 in Ontario, Canada. 